\section{Flood Control and its}

\section{Management}

\author{
Alcoforado FAG* \\ Consultant, CXA-Arquitectura e Engenharia Ltda., Salvador, Bahia, Brazil
}

\begin{abstract}
This manuscript aims to present the international experience in control and management of floods, in order to identify the best practices. In this study, the causes and consequences of the floods, the measures used to control them, the procedures adopted to guarantee the safety of the post-flood cleaning will be presented and the measures to deal with future floods will be outlined. This article is intended, fundamentally, to offer its readers the knowledge on the best practices of control and management of floods around the world.
\end{abstract}

Keywords: Floods; Flood control; Flood management

\section{Introduction}

The society and the economy of any country suffer in many ways after a flood with the loss of lives, vegetation, properties and infrastructure, which means there will be fewer people on the labor force, less agriculture available for locals and for exporting and less businesses to contribute to the country's economy development. There will be mass displacement of people, many of whom may be left homeless and jobless. In order to fill this gap, the government will have to spend at a higher level. The country may have to look for international assistance to supply food and materials to clean and rebuild its infrastructure. While some countries will support voluntarily, other will charge for their efforts, putting the assisted country in debt and at an economic loss.

*Corresponding author: Alcoforado FAG, Consultant, CXA- Arquitectura e Engenharia Ltda., Salvador, Bahia, Brazil, E-mail: falcoforado@gmail.com

Citation: Alcoforado FAG (2018) Flood Control and its Management. J Atmos Earth Sci 1: 005.

Received: September 13, 2018; Accepted: November 15, 2018; Published: November 30, 2018

Copyright: (c) 2018 Alcoforado FAG. This is an open-access article distributed under the terms of the Creative Commons Attribution License, which permits unrestricted use, distribution, and reproduction in any medium, provided the original author and source are credited.
This study is of great importance, because flooding damages properties and endangers humans and all other living things' lives. This study is justified because floods are among the most frequent natural disasters that cause greater economic losses and difficulties to human activities. About $90 \%$ of the damages caused by natural disasters (excluding droughts) are caused by floods and associated water flows. The floods are responsible for the death of almost twice the amount of people as tornadoes and hurricanes put together. The water-related disasters account for $90 \%$ of all disasters in numbers of people affected. Social and economic costs of floods have risen in recent decades and the trend is to continue to rise if an action is not taken. By 2017, natural disasters related to water caused worldwide losses of US\$ 306 billion. Between 1980 and 2016, 90\% of natural disasters were climate-related. In 2016, 31\% of global losses were due to storms, $32 \%$ attributed to flooding and $10 \%$ to extreme temperatures. In addition, this study is justified as there is the prospect that climate change may contribute to increase flooding resulting from rising sea levels and heavy rains in certain regions of the planet.

This manuscript is composed by the following items:

- Causes and Consequences of Floods

- Flood control and flood management

- Flood protection in Europe and North America

- Data on floods in Asia and in the World

- Measures adopted for post-flood cleaning safety

- Benefits from floods

- Netherlands experience in flood prevention and control

- Confronting floods in the future

- Conclusions

\section{Causes and consequences of floods ${ }^{1}$}

Flooding may be caused by many factors such as intense rainfall, strong winds over water, unusual high tides, tsunamis or failure of dams, elevation of retention pond levels or other structures that contain water. Periodic flooding occurs in many rivers, forming a surrounding region known as an alluvial plain. During periods of rain or snow, some of the water is retained in ponds or soil, others are absorbed by grass and vegetation, some evaporate and the rest travels over the land as surface runoff.

Flooding occurs when lakes, riverbeds, soil and vegetation cannot absorb all the water. Water then escapes from land in quantities that cannot be transported into the channels of streams or retained in

1. This part of the manuscript has its content based on articles Source book for sustainable flood mitigation strategies edited by Department for International Development (DFID)[1], Risk Assessment and Control Approaches for Stormwater Flood and Pollution Management edited by Ellis, Scholes, Revitt and Viavattene [2], The Nation's Responses to Flood Disasters: A Historical Account edited by Hessler [3], Flood Risk Management Federal Role in Infrastructure edited by Carter [4], In Europe, High-Tech Flood Control With Nature's Help edited by Broad [5], Disaster and Emergency Planning for Preparedness, Response and Recovery edited by Alexander [6], and Recovery and The engineering deficit in the solution of the floods problem in Brazil edited by Alcoforado[7]. 
natural ponds, lakes, and man-made reservoirs. About $30 \%$ of all rainfall is in form of small runoff and that amount can be increased by the water of the melted snow where it exists. River flooding is usually caused by heavy rains, sometimes increased by snow melting. Rapid flooding, with little or no advance warning, is called a sudden flood. Sudden floods usually result from heavy rains in a relatively small area, or if the area was already saturated with previous precipitation.

Severe winds over water are another cause of flooding. Even when the rain is relatively light, the banks of lakes and bays can be flooded as a result of strong winds such as during hurricanes that blow water to the coastal areas. Another cause is the unusual high tides that occur, sometimes in coastal areas when they are flooded by unusually high tides, especially when composed of strong winds and storms.

Flooding causes many impacts. They damage property and endanger the lives of humans and other living things. Rapid water runoff causes soil erosion and concomitant deposition of sediment at various locations, as well as fish spawning sites and other wildlife habitats, which may become polluted or completely destroyed. Some high and prolonged floods can compromise vehicle traffic in areas that do not have elevated roads. Flooding can interfere with drainage and economic land use, as well as with agriculture. Structural damage can occur in bridge pillars, sewage systems and other structures in the area of floods. Water navigation and hydroelectric power are often hampered. Financial losses due to floods are typically of millions of dollars each year.

According to UNESCO [8], the global average of economic losses caused by floods and droughts is more than US\$ 40 billion a year in all economic sectors. Storms add, on average, another US\$ 46 billion in annual economic losses. The number of deaths, people affected and economic losses varies greatly per year and per continent, with Africa and Asia being the most affected regions by these three indicators. According to several estimates, these numbers are expected to increase up to US $\$ 200-400$ billion by 2030 . Such losses seriously affect water, food and energy security, as well as consuming the bulk of the total flow of development assistance today.

The United Nations Food and Agriculture Organization (FAO) reports that, floods and droughts have caused 83 per cent of losses in plantations and herds between 2003 and 2013 in 67 countries, evidencing the severe impact of climate-related disasters on the agricultural sector. The FAO came to this conclusion after analyzing 140 disasters in 67 countries during that period, affecting at least 250,000 people. An estimated US $\$ 80$ billion a year has been lost in these countries as a result of reduced production, with damage being done to areas most dependent on agriculture, according to a report released on the eve of the Paris Climate Summit.

Global economic damage - including other sectors besides agriculture and all sorts of natural disasters - was estimated at US\$ 1.5 trillion. The annual average of disasters has doubled since 1980. Latin America and the Caribbean have lost US\$ 11 billion in terms of agricultural production, $55 \%$ of cases caused by floods and to a lesser extent by droughts and storms. Asia accounted for about 60 per cent of the total estimated losses in developing countries in that decade US\$ 48 billion - mainly due to the effect of floods in countries such as India, the Philippines and Pakistan. The FAO explained that in terms of production, 333 million tons of cereals, vegetables, meat, milk and other commodities were lost due to natural disasters. To combat these phenomena, FAO called for improvements in information systems on the impact of disasters on agriculture and advances in adaptive capacity and mitigation of effects with increased investment in the sector.

Russi [9] reports that water-related disasters account for $90 \%$ of all disasters in numbers of people affected. Social and economic costs have risen in recent decades and, according to speakers from the High Level Panel on Water and Natural Disasters at the $8^{\text {th }}$ World Water Forum, the trend will continue to rise if an action is not taken. By 2017, natural disasters related to water caused worldwide losses of US \$ 306 billion. Between 1980 and 2016, 90\% of disasters are climate related. In 2016 , of global losses, $31 \%$ were due to storms, $32 \%$ attributed to flooding and $10 \%$ to extreme temperatures.

According to Espere [10], floods or sudden floods are among the most frequent natural disasters that cause greater economic losses and difficulties to human activity. About $90 \%$ of the damage caused by all natural disasters (droughts excluded) is caused by floods and associated water flows (Figure 1). The floods are responsible for the death of almost twice the number of people than are tornadoes and hurricanes put together

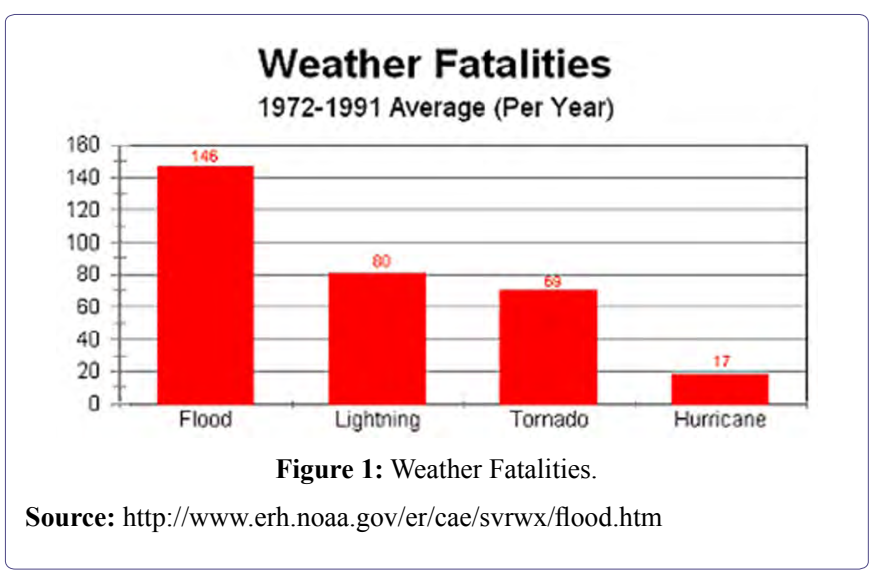

An important impact resulting from the sudden flood is the landslide. A landslide is a geological and climatologically phenomenon that includes a broad spectrum of soil movements, such as rock falls, landslide in depth and surface streams of debris. The landslide is actually just a category of so-called mass movements, which involves the detachment and transport of soil or rocky material slope down. Three factors of influence can be considered in the occurrence of landslides:

- Soil type: its constitution, granulometry and cohesion level

- Declivity of the slope: whose degree defines the angle of repose, according to the layers weight, granulometry and cohesion level

- Soaking water: it contributes to increasing the specific layers weight, reducing the level of cohesion and friction, also responsible for soil consistency and lubricating the slip surfaces

To avoid sliding, one of the measures is replacing the vegetation so that the water that descends on the slopes of the mountains loses speed or infiltrates the soil. The second, who is more secure, is building terraces in form of steps in order to protect the soil from the action of rainwater. 


\section{Flood control and flood management ${ }^{2}$}

\section{Flood control:}

Flood control refers to all methods used to reduce or prevent the damaging effects of flood waters. Some of the common techniques used for flood control are the installation of rock beams, rock rip-raps, sand bags, maintenance of normal slopes with vegetation or application of soil cements on steeper slopes and construction or expansion of drainage. Other methods include dykes, dams, retention basins or detention. Following 2005-Hurricane Katrina disaster in the United States, some areas prefer not to have dykes as flood controls. Communities have chosen to improve drainage structures with detention basins.

Some methods of flood control have been practiced since Antiquity. These methods include planting vegetation to retain excess water, terrace slopes to reduce slope flow, and building alluviums (manmade channels to divert water from flooding), construction of dykes, dams, reservoirs or holding tanks to store extra water during flood periods.

In many countries, flood-prone rivers are often carefully managed. Defenses such as dykes, reservoirs and dams are used to keep rivers from overflowing. A dam is one of the methods of flood protection, which reduces the risk of flooding compared to other methods, once it can help preventing damage. However, it is best to combine dykes with other flood control methods to reduce the risk of a collapsed embankment. When these defenses fail, emergency measures such as sandbags or portable inflatable tubes are used. Coastal floods have been controlled in Europe and North America with defenses such as ocean walls or barrier islands that are narrow, long strips of sand usually parallel to the coastline.

The engineering works that can prevent and mitigate the effects of floods are as follows: 1) On highways, the implantation of steel pipes should take water by gravity away from the road from catchment basins; 2) The severe flooding problems in a city that paved much of its soil would be alleviated in part by the construction of great swimming pools that are large underground water tanks to store the waters; 3) Mandatory placement of permeable drainage floors in huge courtyards of parking lots in malls, supermarkets and cinemas, to allow the water infiltration in part of the ground, being the same for monuments and spaces around buildings; 4) using drains and gutters around all houses to divert rainwater to a reservoir or disposal area; 5) Maintenance, whenever possible, of some green areas so that the water is reabsorbed by the soil; 6) Rectification of rivers and streams, construction of dams and canals in large rivers that extend their containment basins; and 7) Implementation of a civil defense system that should be able to at least warn people and have a scheme to remove them from homes in time with some belongings and accommodate them.

2. This part of the manuscript has its content based on articles Source book for sustainable flood mitigation strategies edited by Department for International Development (DFID)[1], Risk Assessment and Control Approaches for Stormwater Flood and Pollution Management edited by Ellis, Scholes, Revitt and Viavattene [2], The Nation's Responses to Flood Disasters: A Historical Account edited by Hessler [3] Flood Risk Management Federal Role in Infrastructure edited by Carter [4], In Europe, High-Tech Flood Control With Nature's Help edited by Broad [5], Disaster and Emergency Planning for Preparedness, Response and Recovery edited by Alexander [6],The engineering deficit in the solution of the floods problem in Brazil edited by Alcoforado [7], O tempo das catástrofes(The Time of the Disasters) edited byDupuy [11], Processo Decisório (The Decisional Process) edited by Simon [12], Structural vs. Non-Structural Approaches to Disaster Management: Which would you choose? edited by Inada [13] and Flood proofing edited by Chakravartty [14].
Caring to avoid flooding in urban areas is, as follows: 1) keeping streets and sidewalks always clean; 2) cleaning and unclogging manhole and storm drain; 3 ) keeping in the houses the channels and other channels of rainfall free of branches and leaves of trees to avoid clogging and, consequently, return of water; 4) putting garbage bags on the sidewalks only near the time the garbage collection truck will come, preventing them from being drawn into the manhole when it rains; 5) having a drain pump on hand if flooding cannot be avoided; and 6) using Dutch and British flood proof technology as a floating amphibian house that allows buildings to float in the same way as a boat.

Hydrological experts recommend that, in order to avoid flooding in urban areas, the following measures should be adopted: 1) Combating erosion by minimizing sedimentation of natural drainage and built up through rigorous and extensive soil erosion control and irregular disposition of urban garbage and construction rubble, as well as the expansion of the river gutters; 2) Combating waterproofing with the creation of domestic and business reservoirs, as well as the expansion of green areas; 3 ) Forbidding traffic on high traffic avenues when nearby rivers overflow; 4) Implantation of avenues covered by vegetation that, in cases of overflowing rivers or streams, water would be absorbed by the pavement free soil; 5) Constructing great swimming pools to receive rainwater and mini swimming pools in houses and buildings; 6) Investing in small and large streams of the urban center to support the increase of water and act as containment barriers; 7) Review of occupied areas - continuous planning and land-use planning; and 8) Action and planning - preparation of a plan to deal with the occurrence of floods as well as extreme climatic variations, and construction of reservoirs capable of storing billions of cubic meters of water and their use for non-potable purposes.

Correction and prevention measures to minimize flood damage are classified according to their nature into structural and non-structural measures. The structural measures correspond to the works that can be implemented aiming at the correction and / or prevention of problems arising from floods. Non-structural measures are those that seek to prevent and/or reduce the damages and consequences of floods, not by means of work, but by the introduction of norms, regulations and programs that aim at, for example, disciplining land use and occupation, implementing warning systems and the awareness of the population.

The structural measures comprise the engineering works, which can be characterized as intensive and extensive measures. Intensive measures, according to their purpose, can be of four types:

- Acceleration of outflow: pipeline and related works;

- Flow retardation: reservoirs (detention / retention basins), restoration of natural gutters;

- Flow deviation: tunnels of derivation and channels of deviation;

- Individual actions to make buildings flood proof.

On the other hand, the extensive measures correspond to small storage in the basin, restoration of vegetation cover and soil erosion control along the drainage basin.

Structural measures can create a sense of false security and even induce the expansion of occupation of flood areas. Non-structural actions can be effective at lower costs and longer horizons. Non-structural actions seek to discipline territorial occupation, people's behavior and economic activities 
Non-structural measures may be grouped as follows:

- Actions to regulate land use and occupation

- Environmental education focused on the control of diffuse pollution, erosion and waste

- Insurance-flood

- Flood warning and forecasting systems

By delimiting subject-to-flooding areas depending on the risk, it is possible to establish a zoning and the respective regulations for the construction, or for possible individual protection works (such as the installation of floodgates, watertight doors and others) to be included in existing buildings. In the same way, some areas can be expropriated to be used as squares, parks, parking lots and other uses.

In certain cases where structural measures are technically or economically unviable (or even untimely), non-structural measures, such as warning systems, can reduce expected damage in a short-term, with small investments.

Inada [13] discusses issues related to structural and non-structural flood prevention measures. He reports that disaster management and flood protection were a prominent theme at the $2^{\text {nd }}$ Asia-Pacific Water Summit in Chiang Mai. He said that there is a large gap between the groups who prefer "structural" solutions to disaster management and those who prefer "non-structural" solutions. Structural solutions include engineered solutions such as redesigning buildings and designing physical barriers to disaster events in order to reduce damage. Non-structural solutions include social solutions such as early warning, evacuation planning, and emergency response preparedness.

Structural groups, which are often comprised of engineers, insist that only structural solutions can surely prevent countries from economic loss and contribute to the development of the nation. On the other hand, non-structural groups often warn, "Do not trust engineering solutions because they sometime do not work. Early warnings, quick evacuations and emergency response are easy investments."Which solution is more important? This question will cause endless discussions.

Inada [13] reports that the term "resilience" has recently been introduced to disaster management dialogue. The word implies that people should accept damages from a disaster and have plans in place for recovery. As you know, warning, evacuation and emergency response can help save lives; however, it cannot protect properties and physical assets. For structural groups, non-structural solutions are not investments at all. Investments should contribute for development and therefore reduce future expenditures. Structural solutions can protect people's lives and property.

It is a false dilemma to choose between structural and non-structural measures to deal with flooding. We should opt for the two measures. Non-structural measures should be taken in conjunction with structural measures and caution against the latter's failure to do so.

Chakravartty [14] states that any combination of structural and non-structural additions, changes, or adjustments to structures which reduce or eliminate flood damage to real estate or improved real property, water and sanitary facilities, structures and their contents is called flood-proofing. Flood-proofing requires that home owners, builders, architects, engineers and planners engage in detailed assessment of the feasibility of building in high-risk flood-prone areas. Also, flood-proofing structural measures and plans to initiate standby or emergency measures in anticipation to the flood preparation have to be adopted, such as sandbagging and moving furniture and valuables to high floors, blocking openings or safely evacuating. Flood-proofing is not a cure for all flood problems; it is just one of the many available flood damage reduction tools.

Chakravartty [14] reports that the primary objective of flood-proofing is to reduce or avoid the impacts of coastal flooding upon structures. This may include structures elevating above the floodplain, employing designs and building materials which make structures more resilient to flood damage and preventing floodwaters from entering the flood zone, among other measures. When floodwaters surround a building, they impose uplift (vertical) and lateral (horizontal) loads on the structure and sub-structure. The pressures exerted by these loads must be pre-determined in order to design adequate flood-proofing.

Chakravartty [14] states that most commercial and industrial buildings have sufficient anchorage and connections and that they are massive enough to resist to lateral forces produced by floodwaters. In contrast, residential buildings often require special design modifications because they usually have neither the necessary anchorage nor the strength to resist lateral forces. Uplift and lateral forces against a foundation slab and walls caused by the infiltration of floodwaters through the foundation backfill are especially significant in building design and construction.

Chakravartty [14] points out that the decision to use flood-proofing techniques, alone or in combination with flood protection working as dykes requires a cost-benefit analysis. If you are seriously considering adapting any flood damage reduction methods, get the services of a qualified professional engineer to help you select and design the right measure tailored to your particular needs. This is especially important if the house or light-framed structure is or will be located in an area that is susceptible to fast-moving flood waters or if the cost involved is substantial.

Chakravartty [14] says that flood-proofing measures will not necessarily eliminate the risk of the house being flooded. If anticipated benefits exceed the estimated cost, then flood-proofing will be economically justified. One of the main advantages of flood-proofing is that it avoids the need to elevate, demolish or relocate structures and, as a result, it is often much more cost-effective approach to reducing flood risk. Flood-proofing measures are also much more affordable than the construction of elaborate flood protection works such as seawalls and dike systems and also advantageous because it does not require the additional land that would be required to provide the same degree of flood protection through seawalls or dikes.

Flood-proofing measures require the current risk of flooding to be known and communicated to the public through flood hazard mapping studies and flood warning systems. This will allow measures to be appropriately applied and will allow time for residents to vacate flood-proofed buildings in the event of an emergency. In case of dry flood-proofing, it will also allow residents to close barriers in a timely fashion. Although the provision of flood hazard maps and flood warnings bring benefits themselves, it is an additional cost that should be borne when implementing flood-proofing measures. 


\section{Flood management:}

In order to deal with flood risks, it is essential that prevention and precaution measures are adopted to avoid catastrophic events. The Preliminary Environmental Impact Assessment of Floods is an important instrument for the formulation of civil defense plans as it is used to assess, predict and prevent further economic and social damages resulting from floods. It should be noted that preventive or precautionary measures should be based on risk management policies and, above all, be present in the proposals and actions of the Civil Defense in dealing with the floods.

Prevention and precaution are two prudence aspects that are put in front of situations when there is the possibility of damage. These principles should guide any flood protection policy. The distinction between potential and proven risks underpins the parallel distinction between precaution and prevention. Precaution is about potential risks and prevention about proven risks. The potential risk corresponds to a dangerous event that may or may not occur to which no probability can be attributed, while proven risks can be attributed to events with probabilities of occurrence.

The prevention principle is applicable to impacts caused by known floods and from which it is possible to establish a set of causal links that is sufficient to identify the most likely future impacts; that is, when there is already an information history about them. The principle of prevention is intended, in a narrow sense, to avoid immediate, imminent and concrete dangers, according to an immediate logic, as a search, in a broad sense, to remove any future risks, even if not yet entirely determinable, according to a logic prospective of anticipation of future events. In case of certainty of the economic and social damage caused by floods, this must be prevented, as recommended by the principle of prevention.

In case of doubt or uncertainty about floods caused, for example, by global climate change, action must be taken on the basis of the precautionary principle. Floods could have an uncertain occurrence and their impacts would reach different dimensions, which would require specific actions to avoid possible damages with associated risks that should lead to adopting an action that provides the least risk of economic and social damage. The decision to take precautionary measures to address the consequences of global climate change and to avoid its catastrophic consequences of global warming is correct.

Attention must, therefore, be drawn to the distinction between the risk of a future nature, on which the precautionary principle is based, and danger of an immediate nature, associated to the logic of prevention. Prevention means the act of anticipating and precaution, in turn, means to early admission of care. The economic calculation should serve as a basis for decisions related to prevention and precaution. In deciding on the economic alternatives to be adopted, one factor that greatly complicates the solution of a problem is uncertainty. Another complicating factor is insufficient information.

Uncertainty can be minimized and insufficient information can be remedied by the constitution of what is called Big Data. In information technology, the term Big Data refers to a large set of stored data. It is said that Big Data is based on 5 factors: velocity, volume, variety, veracity and value. It's necessary to take the right information, to the right people, at the right time to make decisions. This requires asking the right questions and analyzing the data knowingly to understand the flood dynamics. Big Data enables the analysis of a huge amount of information to show patterns and correlations, in many cases totally unknown. Big Data opens up a wider range of possibilities that can turn into paths to innovation.

It should be noted that decision-making is a process of analysis and choice of several alternatives available, of the course of action to be followed. The decision-making process consists of 6 steps: 1) Perception of the situation; 2) Analysis and definition of the problem; 3) Definition of objectives; 4) Search for solution alternatives; 5) Evaluation and comparison of these alternatives; 6) Choice of the most appropriate alternative (Simon, 2010).

In deciding about the most appropriate alternative, the decision rule used in Decision Theory can be adopted: Maximin, Minimax, Maximax and Minimin. The Maximin criterion is based on a pessimistic view of the problem. Maximin aims to maximize the minimum gain. The alternative to be chosen will be the one that is the best among the worst options of all alternatives considered. Economically, one should determine the minimum economic benefit for each alternative and then choose the alternative with the highest minimum benefit. In the case of floods, the minimum economic benefit would correspond to the smallest difference between the economic loss that would result from them if nothing was done and the cost to avoid them. The Minimax criterion is a decision rule to minimize the possible loss for a worst-case scenario, that is, to choose the lowest of the possible maximum costs. In the case of floods, would be chosen the alternative of minor maximum cost to avoid flooding.

It's possible also adopt the Maximax and Minimin criteria. The Maximax criterion is based on an optimistic view of the problem. The alternative to be chosen would be the one that is the best among the best options of all possible alternatives. Applied to the economic scope, one must determine the maximum economic benefit for each alternative and then choose the alternative with the highest maximum benefit. In the case of floods, the maximum economic benefit would correspond to the greater difference between the economic loss that would result from them if nothing was done and the cost to avoid them. The Minimin criterion is completely opposite to the Maximax criterion: in this one, the decision-makers thinking is pessimistic. In this case, he would examine the worst possible outcome and then choose the alternative that would minimize their losses. In the case of floods, the lowest cost alternative would be chosen to avoid flooding. Finally, one can use the criterion of Hurwicz [15], intermediate between the most pessimistic (Maximin) and the most optimistic (Maximax).

\section{Flood protection in Europe and North America}

London is protected from flooding by an immense mechanical barrier on the River Thames, which is lifted when the water level reaches

3. This part of the manuscript has its content based on articles Source book for sustainable flood mitigation strategies edited by Department for International Development [1], Risk Assessment and Control Approaches for Stormwater Flood and Pollution Management edited by Ellis, Scholes, Revitt and Viavattene [2], The Nation's Responses to Flood Disasters: A Historical Account edited by Hessler [3], Flood Risk Management Federal Role in Infrastructure edited by Carter [4], In Europe, HighTech Flood Control With Nature's Help edited by Broad [5], Disaster and Emergency Planning for Preparedness, Response and Recovery edited by Alexander [6] andThe engineering deficit in the solution of the floods problem in Brazil edited by Alcoforado [7],. 
a certain level. Venice has a similar arrangement, although it is already unable to handle the very high tides. The defenses of London and Venice will be considered inadequate if the level of the sea continues to rise. The largest and most elaborate flood defenses can be found in The Netherlands, where they are referred to as Delta Works with the Oosterschelde dam as their greatest achievement. These works were built in response to the 1953 North Sea flood in the southwestern part of The Netherlands. The Dutch had already built one of the largest dams in the world in the north of the country: the Afsluitdijk (closed in 1932). The St. Petersburg Flood Prevention Facilities Complex was built in Russia to protect St Petersburg from storms. It also has a main traffic function as it completes a circular road around St. Petersburg. Eleven dams stretch 25.4 kilometers and they are eight meters above water level.

Another elaborate system of flood defenses can be found in the province of Manitoba, in Canada. The Red River flows to north from the United States, through the city of Winnipeg (where it meets the Assiniboine River) towards Lake Winnipeg. As is the case with all rivers running north in the temperate zone of the Northern Hemisphere, thawing in the southern sections can cause river levels to rise before the northern sections have a chance to thaw completely. This can lead to devastating floods, as occurred in Winnipeg during the spring of 1950. To protect the city from future floods, the Manitoba government undertook the construction of a huge levee system. The system kept Winnipeg safe during the 1997 flood which devastated many communities north of Winnipeg, including Grand Forks, North Dakota and Ste. Agathe, Manitoba.

In the United States, the New Orleans Metropolitan Area (35\% of which is below sea level) is protected by hundreds of miles of levees and floodgates. This system failed catastrophically with numerous breaks during Hurricane Katrina, in the city proper and in the eastern sections of the metropolitan area, resulting in the flooding of approximately $50 \%$ of the metropolitan area, ranging from a few centimeters to $20 \mathrm{ft}$ (twenty feet) in coastal communities. In a flood prevention act, the United States government offered to buy flood-prone properties in order to prevent repeated post-flood disasters in 1993 throughout the Midwest. Several communities accepted this proposal and the government, in partnership with the state, bought 25,000 properties which were converted into wetlands. These wetlands act like a sponge in storms, and in 1995, when the floods returned, the government did not need to allocate resources in those areas.

\section{Data on floods in Asia and in the World ${ }^{4}$}

Victor [16] states that floods are the most common natural disasters in both developed and developing nations, accounting for almost 40 percent of natural disasters. The Southeast Asian region is especially prone to floods, which, according to the United Nations Office for the Coordination of Humanitarian Affairs, it is estimated that 9.6 million people are currently affected by the floods, with 5.3 million in Thailand alone and that these floods are caused by heavy monsoon showers, typhoons and storms, as a result of climate change.

Victor [16] reports that Southeast Asia is particularly susceptible to the effects of climate change due to its fast growing population - the

4. This part of the manuscript has its content based on articles Flood controlin Southeast Asia edited by Victor [16], The floods in Asia - What's happening and why, edited by Khinmaung-Moore [17], Economic damage caused by significant floods worldwide from 1900 to 2016* (in billion U.S. dollars) edited by STATISTA [18] and The Most Expensive Floods In The World edited by WORLD ATLAS [19] majority of which are still living in poverty - as well as poor food security and diminishing natural resources, that climate change is a result of increasing temperatures which is linked to more intense downpours, heat waves, extreme weather events, greater climate variability and rising sea levels, all of which contribute to the increased frequency and intensity of flooding in Southeast Asia. In Malaysia, over half of the historical state of Penang was submerged in flood waters after hours of torrential rain. Other countries in the region have also been making headlines when it comes to floods particularly, Philippines and Thailand.

Victor [16] states that capacity building in priority concerns such as human resources should be strengthened. Community preparedness is another example of an intervention that can be improved in Southeast Asia. Both governmental and non-governmental operations are often unsustainable, due to lack of funding and community engagement. There is a strong need for governmental organizations to continue developing flood planning strategies beyond mitigation and adaptation.

Khinmaung-Moore [17] states that heavy monsoon rains are continuing to trigger severe flooding across Bangladesh, Nepal and India, that current floods are the worst in decades and are happening during the monsoon. Khinmaung-Moore [17] reported that he can't say if this specific flooding is directly caused by climate change. However, there is a clear relationship between climate change and severe, erratic weather patterns like the ones he is seeing. There have been four floods in Bangladesh in 2017which were bigger and more intense than in previous decades. Poverty means that poor people's are more vulnerable when flooding hits and disaster strikes - particularly as many are almost wholly reliant on the land for their livelihoods. Poverty reduces their options and forces them to live in and grow food in riskier areas. Below-standard drainage, some deforestation and poor infrastructure planning are also compounding the situation. Khinmaung-Moore states that the climate is changing fast and people living in poverty, who are the least responsible for it, are often the most vulnerable to their impacts, including disasters and flooding. Millions of lives and livelihoods are at risk.

STATISTA [18] reports that The Center for Research on the Epidemiology of Disasters released data on the economic damage caused by significant floods worldwide. Up to this date, the flood of August 5, 2011 in Thailand was the most economically damaging flood between 1900 and 2013, causing roughly 40 billion U.S. dollars of damage. Thailand's floods of August 2011 reportedly killed 42 people and occurred in the North and North-Eastern areas of the country. Heavy storm and tropical storm Nock Ten were to blame for the flooding. Nock Ten killed 75 people in Philippines. It also made landfall in China, Vietnam and Laos, where more damage was done and more people died. An estimated 1.5 million people were affected in Thailand. Due to flooding, roughly 650,000 individuals were evacuated from low-lying areas in Thailand and 6,200 acres of rice and other crop fields were submerged by flowing water.

STATISTA [18] reports about China, which had a total population of 1.4 billion individuals as of 2013 , that it is a country heavily affected by flood damage and also has high rank in floods. In one historic event in 1931, over 3.7 million people died due to flooding in China. In 1991, in China, over 210 million people were affected by major flooding. In 1998, over 238 million people were affected by major flood disasters in China. A flood in China in 1998 caused damage 
estimated to be worth 30 billion U.S. dollars. In China, deviation areas are rural areas deliberately flooded in emergencies to protect cities. With natural forest cover, the duration of floods should decrease. Deforestation amplifies the incidents and severity of floods.

(Figure 2) presents data about economic damage in Thailand, China, India, Germany and United States caused by significant floods worldwide from 1900 to 2016 (in billion U.S. dollars).

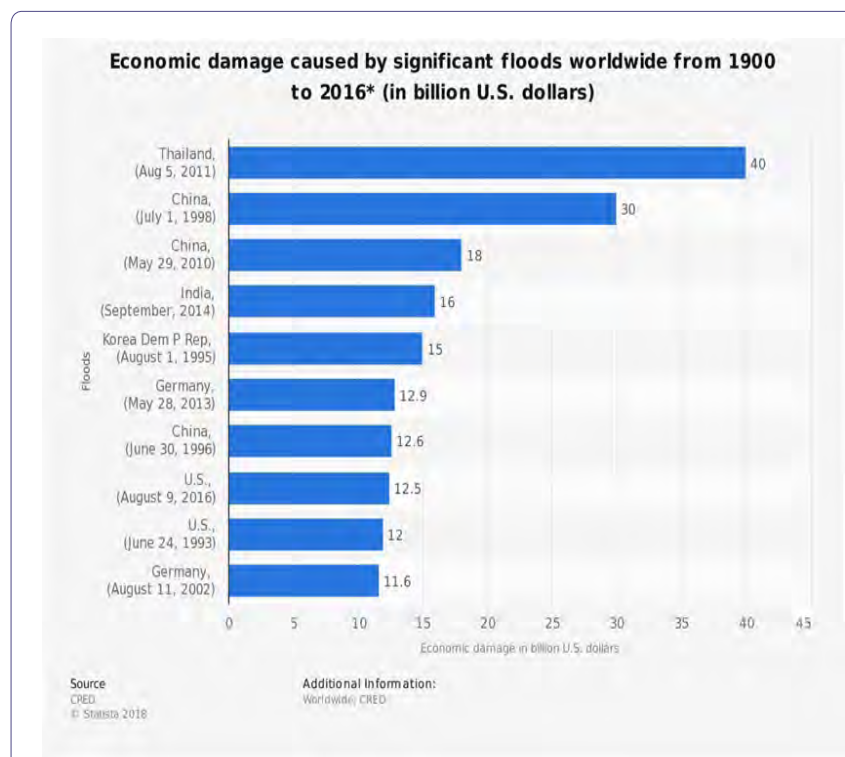

Figure 2: Economic damage caused by significant floods worldwide from 1900 to 2016 (in billion U.S. dollars).

Source:https:/www.statista.com/statistics/267750/economic-damagecaused-by-floods-worldwide/

WORLD ATLAS [19] presents the most expensive floods in the world. Thailand, China and India have all been hit by devastating floods during torrential monsoon rains in recent history. In this article, World Atlas demonstrates the incredible damage that floods can inflict. Between 1900 and 2015, disastrous floods have seriously impacted local economies around the world. Some of the most devastating of these floods occurred in the Southern and Central regions of Asia - specifically in the populous nations China, Thailand, Korea and India. Statistically speaking, only two countries outside of Asia have suffered consequences from massive floods which are severe enough in nature to make it on the list of the 10 most economically devastating floods ever recorded.

The financial damage data, provided by The Center for Research on the Epidemiology of Disasters, put the German floods from May 28,2013 at the sixth position in (Table 1), due to the fact that inflicted $\$ 12.9$ billion USD in damage to the economy to the country. A similar flooding event had taken place in Germany in 2002, with that deluge causing a total loss of $\$ 11.6$ billion USD. The other non-Asian country to make our list, suffering damages from two separate floods as well, is the United States. After a major U.S. flood in 1993, the funds needed to repair all property and return the region back to normal made a total of $\$ 12$ billion USD. Another U.S. flood in 2008 caused damages worth $\$ 10$ billion USD.

\begin{tabular}{|c|c|c|}
\hline \multicolumn{2}{|c|}{ Flood } & $\begin{array}{c}\text { Economic Damage (in billion } \\
\text { U.S. dollars) }\end{array}$ \\
\hline 1 & Thailand, (Aug 5, 2011) & 40.0 \\
\hline 2 & China, (July 1, 1998) & 30.0 \\
\hline 3 & China, (May 29, 2010) & 18.0 \\
\hline 4 & India, (September, 2014) & 16.0 \\
\hline 5 & Korea Dem P Rep, (August 1, 1995) & 15.0 \\
\hline 6 & Germany, (May 28, 2013) & 12.9 \\
\hline 7 & China, (June 30, 1996) & 12.6 \\
\hline 8 & U.S., (June 24, 1993) & 12.0 \\
\hline 9 & Germany, (August 11, 2002) & 11.6 \\
\hline 10 & U.S., (June 9, 2008) & 10.0 \\
\hline
\end{tabular}

Table 1: The most expensive floods in the world.

Source: World Atlas (https://www.worldatlas.com/articles/the-most-catastrophic-floods-in-the-world-and-theirhttps://www.worldatlas.com/articles/the-most-catastrophic-floods-in-the-world-and-their-costly-impact. html)

\section{Measures adopted for post-flood cleaning safety ${ }^{5}$}

Clean-up activities after floods often pose risks to the workers and volunteers involved in such effort. Potential hazards include electrical hazards, carbon monoxide exposure, musculoskeletal hazards, heat or cold, hazards related to motor vehicles, fire, drowning, and exposure to hazardous materials. As flooded disaster sites are unstable, cleaners may encounter sharp fragments, biological hazards in the water, exposed electrical lines, blood or other body fluids, and animal and human remains. When planning and responding to flood disasters, managers should provide workers with safety helmets, goggles, heavy duty gloves, lifejackets, and waterproof boots to toes and with steel insoles.

After the flood waters recede and the cleanup has been done, most folks want to get back into their homes or businesses and start rebuilding. After the floods, the Canadian Department of Public Safety and Emergency Preparedness [20] considers necessary to restore homes to good order as soon as possible to protect health and prevent further damage to the house and its contents. The Canadian Department of Public Safety and Emergency Preparedness has established measures to be taken after floods related to the topics which are as follows: 1) Re-entering your home; 2) Ensure building safety; 3) Water contaminated; 4) Documentation; 5) Cleanup; 6) Recommended flood cleanup equipment; 7) Additional equipment; 8) Water withdrawal; 9) Heating and appliances; 10) Dirt and debris; 11) Floor drains;

5. This part of the manuscript has its content based on articles Source book for sustainable flood mitigation strategies edited by Department for International Development [1], Risk Assessment and Control Approaches for Stormwater Flood and Pollution Management edited by Ellis, Scholes, Revitt and Viavattene [2], The Nation's Responses to Flood Disasters: A Historical Account edited by Hessler [3], Flood Risk Management Federal Role in Infrastructure edited by Carter [4], In Europe, HighTech Flood Control With Nature's Help edited by Broad [5], Disaster and Emergency Planning for Preparedness, Response and Recovery edited by Alexander [6], The engineering deficit in the solution of the floods problem in Brazil edited by Alcoforado [7], After a flood edited by Canadian Department of Public Safety and Emergency Preparedness [20], After the Flood: Emergency Stabilization and Conservation Measures edited by Preservation Assistance Division, U.S. National Park Service [21] and How to Clean Up Safely After a Hurricane or Flood edited by Jolie Kerr [22]. 
12) Structures; 13) Carpets and furniture; 14) Mould; 15) Food and medicine; 16) What to discard; 17) What is salvageable; and, 18) Before moving back in.

Preservation Assistance Division from U.S. National Park Service [21] informs that after the flood waters begin to recede, the focus of relief efforts becomes returning things to normal. During this phase, many historic structures and properties are needlessly lost and damaged through hasty clean-up procedures. The best way to help a historic district, property, or structure prevent additional damage and maintain its integrity and character during these times of duress is with the use of proper caution and concern. Preservation Assistance Division recommends that while the water is receding, one should plan the future steps to rehabilitation and restoration carefully. Each decision made today affects future decisions, which will need to be made tomorrow. The following areas of concern should be addressed during planning: 1) Personal Safety- The First Priority; 2) Documentation- Developing a Condition Assessment Report; 3) Structural Stabilization- Temporary Measures; 4) Drying Out- Natural Ventilation and Time; and, 5) Housekeeping Maintenance- Initial Cleaning and Repair.

An excellent example of measures to be taken after floods is the one presented by Jolie Kerr in her article "How to Clean Up Safely After a Hurricane or Flood". In this article, the author informs that "If you've been hit by either of these - or any other storm - cleaning up can be a nightmare, and few resources tell you where to start". Kerr [22] reports that "Storm cleanup is different from regular and even heavy duty cleaning. There are hazards, health concerns and other issues that go beyond normal cleaning that require specialty products, tools and cleaning techniques, as well as protective gear and safety measures not required in regular cleaning. After a large storm and flooding, many holdings will be full, but often there are unexpected treasures that survive that can be restored. Here are guidelines to follow what can be salvaged." The guidelines of Kerr are presented in the paragraphs below.

After a flood, removing water and drying everything out can be daunting. In addition to utility pumps for water removal, wet/dry vacuums like the Shop Vac, and carpet and upholstery cleaners like the ones made by Rug Doctor and Bissell, can be used without cleaning solutions to extract water from both hard surfaces, like concrete and subflooring, and soft surfaces, like carpet and upholstery. For spot cleaning, a good wet mop, like these suggested by Wire cutter, a New York Times company, will split the difference. If you're willing to invest in a wet/dry vacuum, Wire cutter has a suggestion for you too. Safety is a concern when handling any electric tools in a flooded area, and you should avoid using machines like the Rug Doctor if there is more than a half inch of standing water. Do not enter a flooded space unless you are sure the electricity is turned off.

After standing water has drained or been removed, dampness will persist, and along with that moisture will come mold, mildew and smells. Dehumidifiers, once the water is gone, can help keep the air at a comfortable humidity until you can make bigger repairs. Portable air-conditioning units (but not outdoor or ground-mounted central air units, which can be contaminated with silt) can also help reduce humidity and moisture levels in your home. If a dehumidifier or air-conditioner offers the feature, use the 'extra dry' setting. Both of these options are great while you get lingering moisture out of walls or flooring, or to finish dehumidifying your home once you've made those repairs. Carpet and upholstery cleaners can be used with a premixed odor-eliminating solution or diluted white vinegar (if allowed by manufacturer instructions) to remove those damp, mildewy smells from your floors.

A bleach solution and scrub brush can be used to remove mold from hard surfaces. When cleaning mold, it is important to wear protective gloves and mask, particularly if you suffer from respiratory issues or have a weakened immune system. To treat moderate dampness and mustiness, desiccants and odor absorbers such as Damp rid, silica, the Bad Air Sponge and activated charcoal-based products are all good choices. It's also worth keeping in mind that even with all these tips, you still may want to get a professional mold test for your home - even the best efforts of individuals may not be enough, and you might need professional help. After Katrina, for example, some people needed expensive antimicrobial spraying equipment for their whole home. Do your best to clean up, then keep an eye, ear and nose out for spots on walls, smells, or inexplicable coughs.

Heavily soiled laundry requires special handling, and this is especially true in the case of heavy soiling caused by floodwater. Before doing any wash, ensure that the water supply is clean and uncontaminated, and that your laundry machines are safe to use. If they are not, head to your closest laundromat or dry cleaners. If access to Laundromats or dry cleaners is an issue, check to see if corporate disaster relief services, such as Tide's Loads of Hope program, or volunteer laundering services, like Ladies Who Launder (and Men Too...), are available in your area.

Start by taking the heavily soiled laundry outside to rinse wet or muddy items off using a hose, or place them into a utility sink for pre-rinsing if outdoor space is not available. Allow the items to dry, ideally in the sun, to help prevent mildew from developing, then shake out and brush off any dirt and mud that remains after the initial rinse. To ensure safe handling of contaminated textiles, wear gloves, and consider the use of goggles and/or a mask or a respirator. The C.D.C. recommends disposing of items that have been exposed to sewage spills and groundwater runoff, as well as things like pillows, plush toys, or clothing that has been in floodwater for an extended period of time.

When laundering heavily soiled textiles, it's important to check the water during the rinse cycle to make sure the items are clean. Multiple wash cycles may be needed to fully remove soil and other contaminants. For disinfecting clothes or other laundry, use the hottest water setting that is safe for the fabric type. Provided they are safe to be used in laundry per the manufacturer's instructions, add pine oil disinfectants such as Pine-Sol or lest oil, or phenolic disinfectants like Lysol, or chlorine bleach, at the start of the wash cycle. Once your items are thoroughly cleaned, they may go into a dryer - but not before, as the heat will set stains into soiled textiles.

For your safety when working in wet conditions, wear rubber or insulated footwear, and again, do not enter a flooded space unless you are sure the electricity is turned off. If your home has natural gas service, check for gas leaks before using electrical equipment in your home, including lights. If you have a gas grill, have your canisters checked by a professional before you try using them again. The Environmental Protection Agency recommends wearing gloves and other protective equipment in post-flood conditions, including respirators and goggles. Similarly, the U.S. Consumer Product Safety 
Commission has a safety guide to follow before you walk into a flood-damaged home. If you want to brave returning to your home before the water has fully receded, do so only with the proper equipment.

Snakes and other wildlife will also be a concern, so use caution when working in flooded areas. The American Red Cross recommends employing a wooden stick to turn over upended items that might harbor critters, as well as for scaring away snakes and for moving potentially-live electrical wires. Additionally, floodwater and mud will make flooring slick, creating slip-and-fall hazards. When it comes to insurance claims, it is ideal to have photographs or video of both the interior and exterior of homes, automobiles, boats, etc. before the damage occurred to show their previous condition. Regardless of whether pre-storm photos and videos are available, photos and videos documenting the damage should be taken before cleanup efforts begin.

\section{Benefits from floods ${ }^{6}$}

To benefit from flooding, a new method of coping with flooding is needed. The infrastructure-including dams, levees and floodwalls-has been the traditional response to managing flood risk. However, the successful performance of this infrastructure necessarily eliminates one of the most important ecological processes on Earth: the connection between rivers and floodplains. This connection is what makes river-floodplain systems among the most productive and diverse ecosystems on the planet. Throughout Africa, Asia and Latin America, river-floodplain systems support productive fisheries and agriculture, providing the primary food source for hundreds of millions of people in rural communities. River basins with extensive flood-management infrastructure have lost this essential connection between rivers and floodplains, resulting in dramatic declines in river productivity and biodiversity. In fact, freshwater species are endangered at higher rates than either terrestrial or marine species, in large part to the fragmentation and changes in flow from infrastructure.

Thus, river flood plains present two great challenges to those seeking sustainable management of the world's rivers: the need for actions to reduce flood risk and the need to maintain or restore the connections between rivers and floodplains. At first glance, those objectives seem incompatible. In the article "A Flood of Benefits - Using Green Infrastructure to Reduce Flood Risk", prepared by Jeffrey J. Opperman [23], it is presented how to "green infrastructure" approaches to flood-risk management can address both objectives. This approach incorporates natural features and processes into flood-management projects. The techniques and approaches described here are intended to reduce flood risk for people. However, unlike engineered infrastructure, green infrastructure approaches can also include restoration or conservation of forests, wetlands, rivers and floodplains. These approaches provide not only the primary benefit of flood-risk reduction, but also support a diverse array of other benefits.

6. This part of the manuscript has its content based on articles Source book for sustainable flood mitigation strategies edited by Department for International Development [1], Risk Assessment and Control Approaches for Stormwater Flood and Pollution Management edited by Ellis, Scholes, Revitt and Viavattene [2], The Nation's Responses to Flood Disasters: A Historical Account edited by Hessler [3], Flood Risk Management Federal Role in Infrastructure edited by Carter [4], In Europe, HighTech Flood Control With Nature's Help edited by Broad [5], Disaster and Emergency Planning for Preparedness, Response and Recovery edited by Alexander [6], The engineering deficit in the solution of the floods problem in Brazil edited by Alcoforado [7] and A Flood of Benefits - Using Green Infrastructure to Reduce Flood Risk edited by Jeffrey J. Opperman [23] Barry, JM et al., [24]
The Mississippi River case, prepared by Barry, JM et al., [24] is an excellent example of flood control project which, when they occur, provide economic benefits. The Mississippi Rivercase is reported in the paragraphs below.

In 2011 the lower Mississippi River carried the greatest volume of floodwaters ever recorded, exceeding the historic flood of 1927. In that earlier flood, considered the most destructive river flood in the history of the United States, levees were breached or overtopped in 145 locations, $70,000 \mathrm{~km} 2$ were inundated, and 700,000 people were displaced for weeks to months. Officially hundreds of people died but it is more likely that thousands of rural residents were killed [24]. The flood exposed two primary limitations to river and floodplain management of the time: first, flood management relied excessively on levees (the "levees-only" approach) which presumed that nearly the entire floodplain could be disconnected from river floods. Second, floodplain and river management were uncoordinated. In response to the flood, the U.S. Army Corps of Engineers developed the Mississippi Rivers and Tributaries Project (MR\&T). The MR\&T coordinated levee placement and design, dam development and operations, floodplain management and navigation for the lower Mississippi River basin, including several major tributaries [24]. In addition to replacing a piecemeal approach to river management with a comprehensive system approach, the MR\&T also moved floodplain management away from the "levees only" approach and included floodplain storage and conveyance as critical components of flood-risk management.

Four floodways were designated, portions of the historic floodplain that would reconnect to the river and convey floodwaters during the highest floods. Additionally, four "backwater" or "natural storage" areas exist at the gaps in levees at major tributaries (St. Francis, Yazoo, White and Red rivers). During very large floods, these floodways and backwater storage areas become reconnected to the river and store or convey a considerable proportion of the total flow, thus reducing river stage and stress on levees elsewhere in the system. For example, for the "project design flood" (the maximum flood with a reasonable probability of occurring), the New Madrid floodway is designed to convey nearly $1 / 4$ of the flow and, near the Gulf of Mexico, the channel itself is designed to carry approximately $40 \%$ with $60 \%$ of the flow moving through floodways, primarily the Morganza Floodway in the Atchafalaya Basin [24]. The 2011 flood was the largest that the MR\&T has confronted, with a larger volume than the 1927 flood. The system managed the flood without a single levee breach or death and three of the floodways were activated simultaneously.

The dramatically different outcomes of floods of 1927 and 2011 emphasize the effectiveness of both system-scale's approach to river management and the value of hydro logically connected floodplains, as use of the floodways was essential in reducing flood risk for riverside cities such as Cairo, Illinois, and Baton Rouge and New Orleans in Louisiana. Thus, the MR\&T also illustrates an example of integrating "green" infrastructure (floodways and backwater areas) with engineered infrastructure (dams and levees), although much of the green infrastructure is comprised of heavily modified floodplain surfaces. In addition to providing more effective flood management, the system-scale's approach to water-management infrastructure in the MR\&T provides the opportunity for greater environmental sustainability for the lower Mississippi. During the most recent flood, allowing large volumes of water to be stored and conveyed through the backwater areas and floodways-essentially portions of the historic floodplain-likely provided greater environmental benefits than 
would have been achieved through pre-1927 uncoordinated and "levees only" flood management. The floodways provided foraging habitat for fish and birds (D. Thomas, Illinois Natural History Survey, personal communication) and this may contribute to large recruitment classes of fish populations who benefited from floodplain spawning and rearing, based on results from the 1993 flood in the upper Mississippi [24].

However, the MR\&T was designed essentially for flood control and navigation and, reflecting the values and scientific knowledge of the time, did not strive to promote river-flood plain integrity. Additionally, the Mississippi Basin has experienced three historic floods in less than 20 years and forecasts suggest that flood magnitudes may increase with climate change [24]. River managers may need to analyze whether the current flood ways and backwater areas provide for sufficient flood water storage and conveyance to maintain the integrity of the MR\&T. Thus, the MR\&T could be reassessed and redesigned, both to ensure that it can maintain acceptable flood risks and pursue a broader range of river-floodplain benefits, reflecting current scientific understanding and societal values and expectations.

\section{Netherlands experience in flood prevention and control ${ }^{7}$}

The government of The Netherlands invests heavily in the maintenance of dykes and canals, in the control of waters and in the fight against musk rats, a serious threat to the advanced net of protection against Dutch storms, by weakening the dams with the deep nests that they dig for protect their off spring. Using metal cages and carrot traps, the Flevoland rodent hunters perform a simple (but vital) service for the efficient Dutch defense system, composed of flood control techniques developed since the Middle Ages and by futuristic steel structures operated by computers, which move to control flooding caused by rising water levels after storms.

Dutch thinking is about avoiding the occurrence of catastrophes. The Netherlands has no hurricanes, but faces fierce storms from the northwest, routed to the Dutch coast through the North Sea. After hundreds of years on the edge of the abyss, the Dutch became acutely aware of the consequences of the floods and the need to prevent them in a country where two thirds of the population, including most of the inhabitants of Amsterdam, Rotterdam and The Hague, live below sea level. The Netherlands has mobilized enormous resources to anticipate and minimize the risk of floods. For much of their history, the Dutch conquered lands that were nothing but large marshes, creating elaborate mosaics of dykes that, if placed side by side, would be 80,000 kilometers long.

After the great floods in 1916 and 1953, it was decided that the constant construction, enlargement and reinforcement of dykes would not be possible, especially in densely populated areas. This led to the construction of a series of dams that would protect marsh estuaries and sea arms. In addition, mobile dams were built in places that could not be closed due to the heavy traffic of ships, such as the estuary leading to the port of Rotterdam. In response to the 1953 flood, which

7. This part of the manuscript has its content based on articles Holanda é exemplo na prevenção de enchentes (Netherlands is an example in the flood prevention) edited by GauchaZH Mundo [25], As obras que podem evitar e amenizar os efeitos das enchentes (Works that can prevent and mitigate the effects of the floods) edited by Caldeira [26], Construção de barreira para conter Mar do Norte transformou a Holanda (Construction of barrier to contain North Sea made the Netherlands) edited by Globo Reporter [27], Observations on the successful territorial and development planning from the Netherlands edited by Alcoforado [28], and Dutch Masters:The Netherlands exports flood-control expertiseedited by Iovenko [29] killed more than 1,800 people, the Dutch state has created harsh rules requiring flood dams to be strong enough to withstand storms with a 10,000 year return period, according to computer projections.

The Dutch government currently spends about US\$ 1.3 billion a year on water control. In addition, the water councils spend millions more on the maintenance of dykes and canals, hunting musk rats and pumping water from the "Polderland" - old marshes, lakes and sea areas that have become habitable with the aid of dams. Capital investments in large construction projects add a few billion more to the account. The Delta Plan, a construction program started after the flood of 1953, cost about US\$13 billion and took four decades to get ready.

Built in Rotterdam to combat flooding caused by storms, Maeslantkering is a mobile dam whose extension is equivalent to two Eiffel towers. The project was completed in 1997 and, after testing, only needed to be used once, in November 2007. The new central control unit was equipped with a series of computers that display up-to-date data on water levels, winds and other potential threats to dams built to deal with the North Sea, the Rhine and three other major waterways that cross The Netherlands. Since 1953, Dutch dams have endured almost everything, despite the tragedy that was narrowly avoided in the early 1990 s, leading to the evacuation of 250,000 people and almost the same number of cows and pigs.

In the twentieth century, The Netherlands was basically dedicated to projects of great proportions. Flevoland province was born out of an outbreak of buildings after the 1916 flood. A 30-kilometer-long dam protects the Zuiderzee, an arm of the North Sea, turning its northern portion into a freshwater lake. Although the country has invested heavily in flood control, this is not a waste of money, as it involves careful calculation of the cost-benefit ratio. Dutch thinking has evolved and there are new priorities and methods for increasing flood barriers in a natural way. The Dutch government is investing in a plan called "Space for the Rivers", which aims to reduce floods, giving space for water flow. Last year the country spent about US\$ 100 million in laying 20 million cubic meters of the seabed sand on the coast north of Rotterdam, promoting the formation of a protective barrier.

Iovenko [29] reports that The Netherlands has, for centuries, dealt with flooding and high waters by developing innovative water management techniques and technologies, and in recent years, other countries have been tapping this Dutch expertise. Such expertise in water management is as old as The Netherlands itself, and as global seas rise, the Dutch are still on the front lines in dealing with flooding and sea-level rise caused by climate change. This prowess is not only helping them in their own efforts, but now they are also going all around the world selling their engineering expertise. They are trying to export that expertise that is their growth industry. Coastal cities in the U.S. and elsewhere are hoping Dutch engineering expertise will work for them in fighting back the encroaching seas.

Cities in the United States, in the wake of natural disasters, have also turned to the Dutch both for expertise and inspiration. Following the devastation wrought by Hurricane Katrina in New Orleans in 2005, a delegation of architects, city planners and politicians from Louisiana, including architect David Waggonner, visited The Netherlands. One lesson from the Dutch experience is that not only can large public investments in flood control infrastructure work, but they can 
also be more economical than responding after a disaster. Historically, however, the US has relied more on costly disaster recovery than on programs and infrastructures designed to prevent or mitigate flood-related disasters.

A project in New York that exhibits Dutch design influence is the recently completed renovation of Governors Island. A former fort and military base - and more recently a Coast Guard training facility, Governors Island, which sits in New York Harbor just south of lower Manhattan and west of Brooklyn - was sold to New York State and New York City by the Federal Government for US\$ 1 in 2003 (a small portion remains with the National Park Service). In 2010, a far-reaching plan was undertaken to remake the island as a legacy public park that would be sustainable and enjoyable for many generations to come. The Dutch firm West 8 was chosen to implement the project. A legacy park needs to be above sea level. So, the topography was manipulated and a new level above the 100 -year flood line was created.

\section{Confronting floods in the future}

Europe is at the forefront of flood control technology. With many countries across Europe at or below sea level, the problems of flooding and rising sea levels are ever increasing. Countries such as The Netherlands, with projects such as the Zuiderzee works and the Delta works, can be important models for other countries in the world. These types of gigantic projects can be instruments in combating the increasing effects of global climate change, such as rising sea levels, increasing the frequency and severity of some natural disasters, and even increasing the duration of dry or rainy seasons.

The sheer amount of damage that Hurricane Katrina caused to New Orleans could have been avoided if New Orleans had a flood control system like The Netherlands one. The Katrina result prompted the state of Louisiana to send politicians to The Netherlands to tour the complex and highly-developed flood control system there. Many countries around the world are also at or below sea level and the worst part is the fact that a significant amount of the global population lives on or near the coast. Many of the projects used in Holland could be necessary to combat flooding around the world as a flood of 100 or even 10,000 years. These projects can be key instruments in the fight against global climate change.

The Netherlands, which is the world's leader in flood control and the struggle against the sea for centuries, develops new procedures to deal with water that are constantly being developed and tested. Projects such as underground storage of water, storage of water in reservoirs in large parking garages, and even something simple like turning a playground under normal conditions into a small lake during a heavy rainy season show how The Netherlands is actively trying to counter the dangers of rising sea levels. In Rotterdam, there is even a project to build a 120 -acre floating housing complex, which obviously will not be affected by rising sea levels.

These flood control systems do not always have to be adopted exclusively to prevent flooding, but they can also be used to fight droughts. China recently visited The Netherlands and asked for its help in combating the large-scale drought that is occurring there. The Dutch will help China develop a drought alert system as well as new water resources management programs, and contribute to flood defense research. Flood control will become a growing issue in world politics, and as more and more countries begin to feel the effects of a global rise in sea level, The Netherlands will certainly be at the forefront of this action, as it is considered an example for many countries when it comes to deal with rising sea levels.

\section{Conclusions}

This study has the following conclusions:

- Between 1900 and 2015, disastrous floods have seriously impacted local economies around the world. Some of the most devastating of these floods occurred in the southern and central regions of Asia - specifically in the populous nations of China, Thailand, Korea and India. Thailand, China and India have all been hit by devastating floods during torrential monsoon rains in recent history. The high economic damage caused for floods in several countries of the world justify investment in control and management of floods

- There is need to exercise flood control with the adoption of structural and non-structural measures. The structural measures correspond to the engineering works that can be implemented aiming at the correction and/or prevention of problems arising from floods. Non-structural measures are those that seek to prevent or reduce the damage or consequences of floods, not by means of engineering works, but by the introduction of standards, regulations and programs that aim at, for example, disciplining land use and occupation, the implementation of warning systems and the awareness of the population

- In order to deal with flood risks, it is essential that prevention and precaution measures are adopted to avoid catastrophic events. Prevention and precaution are two aspects of prudence that are put in front of situations when there is the possibility of damage. These principles should guide any flood protection policy. The distinction between potential risk and proven risk underpins the parallel distinction between precaution and prevention. Precaution is about potential risks and prevention is about proven risks. The potential risk corresponds to a dangerous event that may or may not occur to which no probability can be attributed, while proven risks can be attributed to events with their probabilities of occurrence

- The Netherlands, which is the world leader in flood control and struggle against the sea for centuries, develops new procedures to deal with water that are constantly being developed and tested. The Netherlands has, for centuries, dealt with flooding and high waters by developing innovative water management techniques and technologies, and in recent years, other countries have been tapping this Dutch expertise. Coastal cities in the U.S. and elsewhere are hoping Dutch know how will work for them as well in fighting back the encroaching seas

- Clean-up activities after floods often pose risks to the workers and volunteers involved in the effort. After the floods, it's necessary to restore homes to good order as soon as possible in order to protect health and prevent further damage to the house and its contents

- The integrating "green" infrastructure (floodways and backwater areas) with engineered infrastructure (dams and levees) could provide more effective flood management. This model of water-management infrastructure provides the opportunity for greater environmental sustainability, allowing large volumes of water to be stored and conveyed through the backwater areas and floodways likely provided greater environmental benefits 
The findings of this study could be further enriched if the author had visited institutions dedicated to flood planning and control in several countries around the world. Future research on flood planning and control should be undertaken with visits to countries most affected by flooding and to research institutions around the world where studies about flood control and management are conducted.

\section{References}

1. https://assets.publishing.service.gov.uk/media/57a08c8540f0b652dd0013a6/R8159-Source_Book.pdf.

2. Ellis B, Scholes L, Revitt M, Viavattene C (2008) Risk Assessment and Control Approaches for Stormwater Flood and Pollution Management SWITCH 1-11.

3. https://www.floods.org/PDF/hist_fpm.pdf.

4. Carter N (2005) Flood Risk Management Federal Role in Infrastructure. CRS Report for Congress, Denton, Texas,USA.

5. Broad W (2005) In Europe, High-Tech Flood Control With Nature's Help. The new York times, New York, USA.

6. Alexander D (2015) Disaster and Emergency Planning for Preparedness, Response and Recovery. Natural Hazard Science, Oxford Research Encyclopedia, Oxford University Press, New York, USA.

7. Alcoforado F (2018) The engineering deficit in the solution of the floods problem in Brazil.

8. http://unesdoc.unesco.org/images/0026/002615/261579por.pdf.

9. https://www.correiobraziliense.com.br/app/noticia/forummundialdaagua/2018/03/20/interna_forum_mundial_agua,667251/catastrofes-relacionados-a-agua-causaram-perdas-de-us-306-bilhoes.shtml.

10. Espere (2006) Flashfloods. Educational Network on Climate, Environmental Science Published for Everybody Round the Earth, Norwich, UK.

11. Dupuy J (2011) [O tempo das catástrofes]. Realizações Editora, São Paulo, Brazil.

12. http://pdherbert.blogspot.com.br/2010/10/ou-podemos-definir-em-6etapas-essa.html.

13. Inada Y (2013) Structural vs. Non-Structural Approaches to Disaster Management: Which would you choose? thrive.
14. https://www.linkedin.com/pulse/flood-proofing-sandeep-chakravartty/

15. Hurwicz L, Arrow K (1978) Studies in resource allocation processes. Cambridge University Press, Cambridge, UK.

16. Victor P (2017) Flood control in Southeast Asia. The asean post, Kuala Lumpur, Malaysia.

17. Khinmaung-Moore J (2017) The floods in Asia - What's happening and why.relifweb.

18. STATISTA (2018) Economic damage caused by significant floods worldwide from 1900 to $2016^{*}$ (in billion U.S. dollars). The Statistical Portal, Statista, New York, USA.

19. WORLD ATLAS (2018) The most expensive floods in the world. World facts, World Atlas, Canada.

20. Canadian Department of Public Safety and Emergency Preparedness (2018) After a flood. Canadian Department of Public Safety and Emergency Preparedness, Government of Canada, Canada.

21. Preservation Assistance Division, U.S. National Park Service (2018) After the Flood: Emergency Stabilization and Conservation Measures. Washington, D.C.,USA.

22. Kerr J (2017) How to Clean Up Safely After a Hurricane or Flood (2017). The new York times, New York, USA.

23. Opperman JJ (2014) Flood of Benefits - Using Green Infrastructure to Reduce Flood Risk .Conservation GATEWAY.

24. https://www.conservationgateway.org/ConservationPractices/Freshwater/ HabitatProtectionandRestoration/Documents/Mississippi\%20River\%20 Case\%20Study.pdf

25. Gauchazh Mundo (2012) [Holanda é exemplo na prevenção de enchentes]. The new york times, New York, USA.

26. Caldeira J (2013) [As obras que podem evitar e amenizar os efeitos das enchentes]. O JORNAL DE TODOS OS BRASIS.

27. Globo Repórter (2014) [Construção de barreira para conter Mar do Norte transformou a Holanda, Globo Reporter].

28. Alcoforado F (2017) Observations on the successful territorial and development planning from The Netherlands. 


\section{II}

Journal of Anesthesia \& Clinical Care

Journal of Addiction \& Addictive Disorders

Advances in Microbiology Research

Advances in Industrial Biotechnology

Journal of Agronomy \& Agricultural Science

Journal of AIDS Clinical Research \& STDs

Journal of Alcoholism, Drug Abuse \& Substance Dependence

Journal of Allergy Disorders \& Therapy

Journal of Alternative, Complementary \& Integrative Medicine

Journal of Alzheimer's \& Neurodegenerative Diseases

Journal of Angiology \& Vascular Surgery

Journal of Animal Research \& Veterinary Science

Archives of Zoological Studies

Archives of Urology

Journal of Atmospheric \& Earth-Sciences

Journal of Aquaculture \& Fisheries

Journal of Biotech Research \& Biochemistry

Journal of Brain \& Neuroscience Research

Journal of Cancer Biology \& Treatment

Journal of Cardiology \& Neurocardiovascular Diseases

Journal of Cell Biology \& Cell Metabolism

Journal of Clinical Dermatology \& Therapy

Journal of Clinical Immunology \& Immunotherapy

Journal of Clinical Studies \& Medical Case Reports

Journal of Community Medicine \& Public Health Care

Current Trends: Medical \& Biological Engineering

Journal of Cytology \& Tissue Biology

Journal of Dentistry: Oral Health \& Cosmesis

Journal of Diabetes \& Metabolic Disorders

Journal of Dairy Research \& Technology

Journal of Emergency Medicine Trauma \& Surgical Care

Journal of Environmental Science: Current Research

Journal of Food Science \& Nutrition

Journal of Forensic, Legal \& Investigative Sciences

Journal of Gastroenterology \& Hepatology Research
Journal of Gerontology \& Geriatric Medicine

Journal of Genetics \& Genomic Sciences

Journal of Hematology, Blood Transfusion \& Disorders

Journal of Human Endocrinology

Journal of Hospice \& Palliative Medical Care

Journal of Internal Medicine \& Primary Healthcare

Journal of Infectious \& Non Infectious Diseases

Journal of Light \& Laser: Current Trends

Journal of Modern Chemical Sciences

Journal of Medicine: Study \& Research

Journal of Nanotechnology: Nanomedicine \& Nanobiotechnology

Journal of Neonatology \& Clinical Pediatrics

Journal of Nephrology \& Renal Therapy

Journal of Non Invasive Vascular Investigation

Journal of Nuclear Medicine, Radiology \& Radiation Therapy

Journal of Obesity \& Weight Loss

Journal of Orthopedic Research \& Physiotherapy

Journal of Otolaryngology, Head \& Neck Surgery

Journal of Protein Research \& Bioinformatics

Journal of Pathology Clinical \& Medical Research

Journal of Pharmacology, Pharmaceutics \& Pharmacovigilance

Journal of Physical Medicine, Rehabilitation \& Disabilities

Journal of Plant Science: Current Research

Journal of Psychiatry, Depression \& Anxiety

Journal of Pulmonary Medicine \& Respiratory Research

Journal of Practical \& Professional Nursing

Journal of Reproductive Medicine, Gynaecology \& Obstetrics

Journal of Stem Cells Research, Development \& Therapy

Journal of Surgery: Current Trends \& Innovations

Journal of Toxicology: Current Research

Journal of Translational Science and Research

Trends in Anatomy \& Physiology

Journal of Vaccines Research \& Vaccination

Journal of Virology \& Antivirals

Submit Your Manuscript: http://www.heraldopenaccess.us/Online-Submission.php 